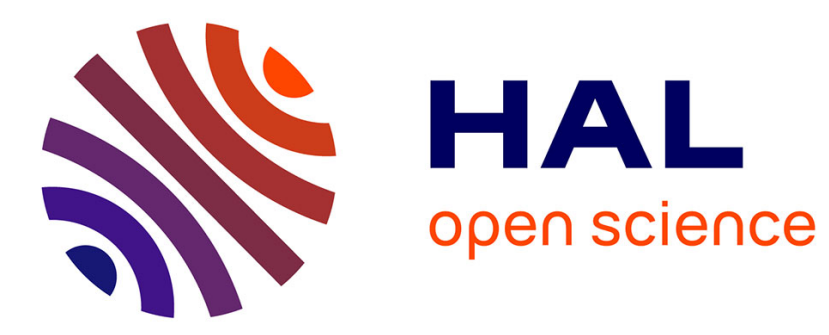

\title{
Relative reaction rates in rotational and vibrational excitation of N2(C 3Пu) by Ar*(3P0 ) and Ar*(3P2) metastable atoms
}

N. Sadeghi, T.D. Nguyen

\section{- To cite this version:}

N. Sadeghi, T.D. Nguyen. Relative reaction rates in rotational and vibrational excitation of N2(C 3Пu) by $\operatorname{Ar}^{*}(3 \mathrm{P} 0)$ and $\mathrm{Ar}^{*}(3 \mathrm{P} 2)$ metastable atoms. Journal de Physique Lettres, 1977, 38 (14), pp.283-285. 10.1051/jphyslet:019770038014028300 • jpa-00231377

\section{HAL Id: jpa-00231377 https://hal.science/jpa-00231377}

Submitted on 1 Jan 1977

HAL is a multi-disciplinary open access archive for the deposit and dissemination of scientific research documents, whether they are published or not. The documents may come from teaching and research institutions in France or abroad, or from public or private research centers.
L'archive ouverte pluridisciplinaire HAL, est destinée au dépôt et à la diffusion de documents scientifiques de niveau recherche, publiés ou non, émanant des établissements d'enseignement et de recherche français ou étrangers, des laboratoires publics ou privés. 


\title{
RELATIVE REACTION RATES IN ROTATIONAL AND VIBRATIONAL EXCITATION OF $\mathbf{N}_{2}\left(C^{3} \Pi_{u}\right)$ BY $A{ }^{*}\left({ }^{3} P_{0}\right)$ AND $A r^{*}\left({ }^{3} P_{2}\right)$ METASTABLE ATOMS
}

\author{
N. SADEGHI and T. D. NGUYEN
}

Laboratoire de Spectrométrie Physique $\left({ }^{*}\right)$

Université Scientifique et Médicale de Grenoble, B.P. 53, 38041 Grenoble Cedex, France

(Reşu le 18 avril 1977, accepté le 13 juin 1977)

\begin{abstract}
Résumé. - Le transfert d'excitation entre $\operatorname{Ar}\left({ }^{3} \mathrm{P}_{0}\right), \operatorname{Ar}\left({ }^{3} \mathrm{P}_{2}\right)$ et molécules d'azote est étudié par la technique de post-décharge. D'une part, la décroissance des populations des atomes métastables d'argon est comparée à celle des intensités des bandes d'émission du système second positif de $\mathrm{N}_{2}$. D'autre part, une perturbation sélective est réalisée sur l'un des niveaux $\operatorname{Ar}\left({ }^{3} \mathrm{P}_{0}\right), \operatorname{Ar}\left({ }^{3} \mathrm{P}_{2}\right)$ par la technique de pompage optique utilisant un laser à colorant accordable; les variations relatives obtenues sur l'intensité des bandes d'émission de $\mathbf{N}_{2}$ ont permis de déterminer le rapport des coefficients de réaction de transfert d'excitation vibrationnelle et rotationnelle de $\mathrm{N}_{2}\left(\mathrm{C}^{3} \Pi_{\mathrm{u}}\right)$ par $\operatorname{Ar}\left({ }^{3} \mathrm{P}_{0}\right)$ et $\operatorname{Ar}\left({ }^{3} \mathrm{P}_{2}\right)$.
\end{abstract}

\begin{abstract}
The energy transfer reaction between $\operatorname{Ar}\left({ }^{3} \mathrm{P}_{0}\right), \operatorname{Ar}\left({ }^{3} \mathrm{P}_{2}\right)$ and molecules of $\mathrm{N}_{2}$ was studied in the afterglow of a pulsed electrodeless discharge. The population decays of the metastable argon atoms and the intensity decays of the nitrogen second positive emission bands were monitored simultaneously. A dye laser was used to selectively depopulate each metastable argon species and the relative variations were checked on the intensity of the nitrogen second positive bands. Relative reaction rates in rotational and vibrational excitation of $\mathrm{N}_{2}\left(\mathrm{C}^{3} \Pi_{u}\right)$ by $\operatorname{Ar}\left({ }^{3} \mathrm{P}_{0}\right)$ and $\operatorname{Ar}\left({ }^{3} \mathrm{P}_{2}\right)$ were obtained.
\end{abstract}

1. Introduction. - The energy transfer by collisions between excited argon atoms in the $\left(3 p^{5} 4 s\right)$ levels and nitrogen molecules has been a subject of repeated investigations during the last few years ([1] to [7]). This is related not only to its fundamental importance in understanding the energy transfer processes in general but also in relation to the electron beam excited Ar- $\mathrm{N}_{2}$ laser for which the specific contribution of each excited argon level to the population inversion are not well known. It has generally been accepted in previous investigations that the whole populations of the argon $3 p^{5} 4 s$ levels, usually designated by ${ }^{3} \mathrm{P}_{2}$, ${ }^{3} \mathrm{P}_{1},{ }^{3} \mathrm{P}_{0}$ and ${ }^{1} \mathbf{P}_{1}$, participate in the excitation transfer leading to the formation of the excited state $\mathrm{N}_{2}\left(\mathrm{C}^{3} \Pi_{\mathrm{u}}\right)$. Numerous results have been obtained in these early studies. However, some controversies remain, for example it is not clear whether the collision transfer process involves complex formation, in which case the observed first positive band $\mathrm{N}_{2}\left(\mathrm{~B}^{3} \Pi_{\mathrm{g}} \rightarrow \mathrm{A}^{3} \Sigma_{\mathrm{u}}^{+}\right)$is explained [1], or if it involves direct Frank-Condon excitation [6]. Furthermore, excepting Chen et al. [7], no attempt was made in previous studies to determine

(*) Laboratoire associé au C.N.R.S. the specific contribution of each argon atom species in the transfer. For this purpose a program of experiments is at present under way in our laboratory with the aim of specifying the efficiency of each energy donor state argon ${ }^{3} \mathrm{P}_{2},{ }^{3} \mathrm{P}_{1},{ }^{3} \mathrm{P}_{0}$ and ${ }^{1} \mathrm{P}_{1}$ in the formation of the $\mathrm{N}_{2}\left(\mathrm{C}^{3} \Pi_{\mathrm{u}}, v^{\prime}, K^{\prime}\right)$ level in each vibrational and rotational state. In the present paper we report the first experimental results concerning the relative values of the coefficient rates for the production of $\mathrm{N}_{2}\left(\mathrm{C}^{3} \Pi_{\mathrm{u}}, v^{\prime}, K^{\prime}\right)$ by argon ${ }^{3} \mathrm{P}_{2}$ and ${ }^{3} \mathrm{P}_{0}$ metastable atoms.

The experiment was performed in the late afterglow where the populations of the ${ }^{3} \mathbf{P}_{1}$ and ${ }^{1} \mathbf{P}_{1}$ levels were very weak and we have verified that their contribution to the energy transfer can be neglected compared to that of $\operatorname{Ar}\left({ }^{3} \mathrm{P}_{2}\right)$ and $\operatorname{Ar}\left({ }^{3} \mathrm{P}_{0}\right)$. We used the stationary afterglow technique in a $\mathrm{HF}$ pulsed electrodeless discharge applied to a $\mathrm{Ar}: \mathrm{N}_{2}=1000: 1$ gas mixture at the total pressure of about 0.2 torr and contained in a quartz cylindrical cell (diameter $=7 \mathrm{~cm}$; length $=30 \mathrm{~cm}$ ).

This technique provided the observation of $\mathrm{N}_{2}\left(\mathrm{C}^{3} \Pi_{\mathrm{u}}\right)$ produced only by transfer from argon metastables. The time dependence study associated with an original perturbation method based on the 
optical pumping technique, utilizing a tunable dye laser, was used. It enables one of the metastable argon levels to be selectively depopulated and simultaneously provides a check of the relative variation of the population of each excited $\mathrm{N}_{2}\left(\mathrm{C}^{3} \Pi_{\mathrm{u}}, v^{\prime}, K^{\prime}\right)$ level.

2. Experiment. - The major part of our experimental system has already been described in detail elsewhere [8]. We report here briefly pertinent features. A weak pressure ( 0.2 torr) was used in order (1) to , avoid the rotational relaxation of $\mathrm{N}_{2}\left(\mathrm{C}^{3} \Pi_{\mathrm{u}}, v^{\prime}, K^{\prime}\right)$ molecules before radiative emission, (2) to ensure lower quenching efficiency of both metastable atoms and $\mathrm{N}_{2}\left(\mathrm{C}^{3} \Pi_{\mathrm{u}}\right)$ molecules by argon and nitrogen, and (3) to minimize the formation of $\mathrm{N}_{2}\left(\mathrm{C}^{3} \Pi_{\mathrm{u}}\right)$ by the nitrogen atom-atom recombination process and by the energy pooling process from two metastable $\mathrm{N}_{2}\left(\mathrm{~A}^{3} \Sigma\right)$ molecules [9]. The $\mathrm{HF}(33 \mathrm{MHz})$ power used for discharge was maintained at a low level, near the discharge cut-off, to minimize the electron density in order to reduce the argon metastable atom relaxation by electron collisions and to avoid the $\operatorname{Ar}\left({ }^{3} \mathrm{P}_{1}\right)$ and $\operatorname{Ar}\left({ }^{1} \mathrm{P}_{1}\right)$ production by electronic collision transfer from $\operatorname{Ar}\left({ }^{3} \mathrm{P}_{2}\right)$ and $\operatorname{Ar}\left({ }^{3} \mathrm{P}_{0}\right)$. The population decays of the $\operatorname{Ar}\left({ }^{3} \mathrm{P}_{2}\right)$ and $\operatorname{Ar}\left({ }^{3} \mathrm{P}_{0}\right)$ were measured by an optical absorption technique. The intensity of the $\mathrm{N}_{2}\left(\mathrm{C}^{3} \Pi_{\mathrm{u}} \rightarrow \mathrm{B}^{3} \Pi_{\mathrm{g}}\right)$ emission was detected by means of a cooled photomultiplier associated with a photon counting system. Both argon metastable decay and nitrogen second positive emission intensity signals were stored simultaneously in separate multichannelanalysers.
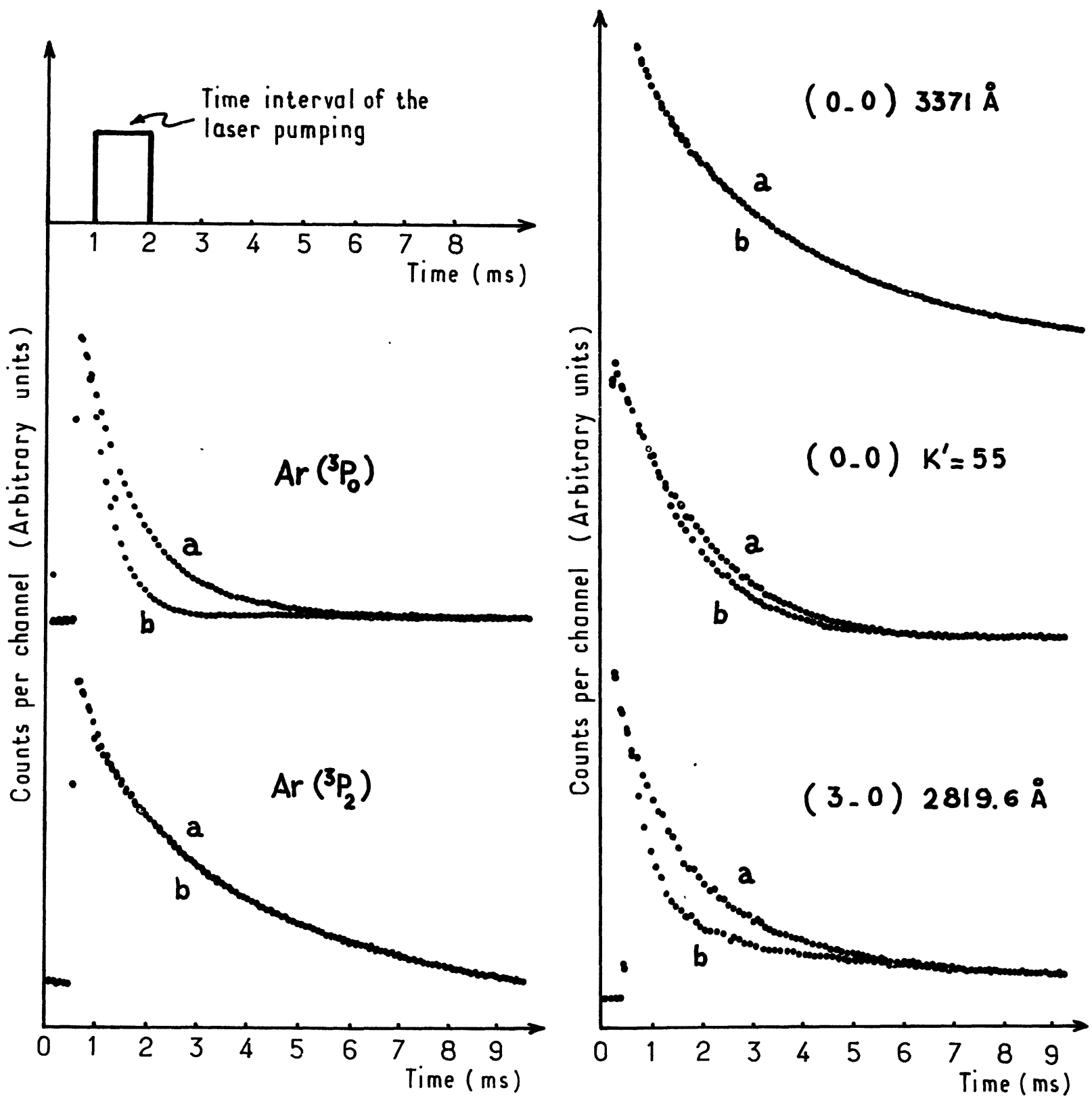

FIG. 1. - Perturbation produced on the $\operatorname{Ar}\left({ }^{3} \mathrm{P}_{0}\right)$ population by laser pumping on the $\operatorname{Ar}\left({ }^{3} \mathrm{P}_{0}\right)$ level with the $7724 \AA$ laser line, and relative variations of the intensity of $\mathrm{N}_{2}\left(C^{3} \Pi_{\mathrm{u}} \rightarrow \mathrm{B}^{3} \Pi_{\mathrm{g}}\right)$ emission ; $(a)$ without laser pumping, $(b)$ with laser pumping. 
TABLE I

Ratio of the reaction coefficients for the high rotational levels of $\mathrm{N}_{2}\left(\mathrm{C}^{3} \Pi_{\mathrm{u}}, v^{\prime}=0\right)$ state excitation by energy transfer from $\operatorname{Ar}\left({ }^{3} \mathrm{P}_{0}\right)$ and $\operatorname{Ar}\left({ }^{3} \mathrm{P}_{2}\right)$ metastable atoms

$\begin{array}{ccccccccccr}\frac{K^{\prime}}{-} & 46 & 47 & 48 & 49 & 50 & 51 & 52 & 53 & 54 & 55 \\ \frac{k_{0}\left({ }^{3} \mathrm{P}_{0} \rightarrow v^{\prime}=0, K^{\prime}\right)}{k_{2}\left({ }^{3} \mathrm{P}_{2} \rightarrow v^{\prime}=0, K^{\prime}\right)} & - & - & - & - & - & - & - & - & - & - \\ & 0.5 & 0.6 & 0.9 & 1.1 & 1.4 & 2.5 & 2.9 & 5.2 & 7.5 & 9.5\end{array}$

For the optical pumping we used a model 375 tunable dye laser pumped by a Krypton-Ion laser model 171 Spectra-Physics. The tunable CW dye laser operated with the Nile Blue dye in multimode with a spectral bandwidth of $0.3 \AA$ and a power output about $100 \mathrm{~mW}$. The laser beam, after being chopped by a rotating disk, was expanded before crossing the discharge cell following its axis. The rotating disk allowed the argon metastable atoms to be pumped by the laser beam in the afterglow during only a small time interval, typically of the order of $1 \mathrm{~ms}$.

3. Results. - The nitrogen second positive emission spectrum, resolved by use of a $1.5 \mathrm{~m}$, SOPRA, Ebert-Fastie scanning monochromator in the afterglow of our experiment, closely resembles that obtained by Stedman and Setser [1].

The typical population decay curves obtained in our experiment are shown in figure 1. For easy comparison we have superposed, for each population scanned, the two curves obtained respectively (a) without laser perturbation and (b) with laser perturbation. The curves were performed with the laser pumping on the $\operatorname{Ar}\left({ }^{3} \mathrm{P}_{0}\right)$ level, using $7724 \AA$ dye laser line. Similar results were obtained with the laser pumping on the $\operatorname{Ar}\left({ }^{3} \mathrm{P}_{2}\right)$ level with the $7635 \AA$ dye laser line.

Examination of figure 1 leads to some observations : (1) the $\operatorname{Ar}\left({ }^{3} \mathrm{P}_{0}\right)$ level was depopulated by over $90 \%$, (2) the selective perturbation on the $\operatorname{Ar}\left({ }^{3} \mathrm{P}_{0}\right)$ level was obtained since the $\operatorname{Ar}\left({ }^{3} \mathrm{P}_{2}\right)$ population was practically not modified, (3) the transfer efficiency of the perturbation on the $\mathrm{N}_{2}\left(\mathrm{C}^{3} \Pi_{\mathrm{u}}\right)$ state depends on the vibrational and the rotational quantum numbers $v^{\prime}$ and $K^{\prime}$.
Numerical investigations of the relative perturbations have shown that the low rotational levels of $\mathrm{N}_{2}\left(\mathrm{C}^{3} \Pi_{\mathrm{v}}\right)_{v^{\prime}=0,1}$ were populated preferentially by transfer from $\operatorname{Ar}\left({ }^{3} \mathrm{P}_{2}\right)$; and the vibrational levels $v^{\prime}=2$ and 3 and the high rotational levels of the $v^{\prime}=0$ state were excited by both $\operatorname{Ar}\left({ }^{3} \mathrm{P}_{2}\right)$ and $\operatorname{Ar}\left({ }^{3} \mathrm{P}_{0}\right)$ atoms. The measurements of the metastable atom densities and the perturbation rates of $\mathrm{N}_{2}\left(\mathrm{C}^{3} \Pi_{\mathrm{u}} \rightarrow \mathrm{B}^{3} \Pi_{\mathrm{g}}\right)$ emission enabled us to determine the relative values of the coefficient rates for their production by $\operatorname{Ar}\left({ }^{3} \mathrm{P}_{0}\right)$ and $\operatorname{Ar}\left({ }^{3} \mathrm{P}_{2}\right)$. Experimental results relative to the high rotational levels of $\mathrm{N}_{2}\left(\mathrm{C}^{3} \Pi_{\mathrm{u}}\right)_{v^{\prime}=0}$ are given in table $\mathrm{I}$.

For the $\mathrm{N}_{2}\left(\mathrm{C}^{3} \Pi_{\mathrm{u}}\right)_{v^{\prime}=2,3}$ levels, checked by $\mathrm{N}_{2}\left(\mathrm{C}^{3} \Pi_{\mathrm{u}} \rightarrow \mathrm{B}^{3} \Pi_{\mathrm{g}}\right)(2-0)$ and (3-0) band head emissions, we have found for $k_{0} / k_{2}$ respectively 3 and $>60$. The accuracy of these results is about $20 \%$.

It is interesting to point out from these results that although the vibrational level $v^{\prime}=2$ and the rotational level $v^{\prime}=0, K^{\prime}=48$ have approximately the same energies (they are both near the $\operatorname{Ar}\left({ }^{3} \mathrm{P}_{2}\right.$ ) energy level) their relative coefficient rates are not the same. The same remark can be made for the $v^{\prime}=3$ level and the $\left(v^{\prime}=0, K^{\prime}=55\right)$ rotational level which lie near the $\operatorname{Ar}\left({ }^{3} \mathrm{P}_{0}\right)$ energy level. The resonance rule is not applicable in energy transfer between excited atoms and molecules and it seems evident that the high rotational levels of $\mathrm{N}_{2}\left(\mathrm{X}^{1} \Sigma_{\mathrm{g}}\right)$ state contributes to the formation of the high rotational levels of $\mathrm{N}_{2}\left(C^{3} \Pi_{\mathrm{u}}\right.$, $v^{\prime}=0$ ) state by energy transfer from $\operatorname{Ar}\left({ }^{3} \mathrm{P}_{2}\right)$.

Acknowledgments. - The authors wish to thank the other members of their research group, particularly Pr. J. C. Pebay-Peyroula and Dr. M. Chenevier for helpful discussions.

\section{References}

[1] Setser, D. W., Stedman, D. H. and Coxon, J. A., J. Chem. Phys. 53 (1970) 1004.

[2] Bochkova, O. P., Chernisheva, N. B. and Tolmachev, Yu. A., Opt. Spectrosc. 36 (1974) 19.

[3] Piper, L. G., Velazco, J. E. and Setser, D. W., J. Chem. Phys. 59 (1973) 3323.

[4] Ricard, A. and Deschamps, J., J. Physique Colloq. 34 (1973) C2-123.
[5] Stokes Fishburne, E., J. Chem. Phys. 47 (1967) 58.

[6] Krenos, J. and Bel Bruno, J., J. Chem. Phys. 65 (1976) 5017.

[7] Chen, C. H., Payne, M. G., Hurst, G. S. and Judish, J. P., J. Chem. Phys. 65 (1976) 4028.

[8] Nguyen, T. D., Sadeghi, N. and Pebay-Peyroula, J. C., Chem. Phys. Lett. 29 (1974) 242.

[9] Hays, G. N. and Oskam, H. J., J. Chem. Phys. 59 (1973) 1507. 